\title{
A Research on Indicators of Selecting Partner of Supply Chain in Construction Industry
}

\author{
Chenhua Cui \\ School of architecture, Xianyang Vocational Technical College, No 1 tongyi Road, Fengwei New \\ District, Xianyang City, Shaanxi Province, China. \\ 1449202824@qq.com.
}

Keywords: Supply chain (SC); Partner; Index; Selection; Weight; Structure; AHP

\begin{abstract}
Partner of SC in construction industry has been discussed in the industry for many years, In this paper, I thoroughly research the problem on " a construction enterprise how to can select the best, the most effective partner in its own SC", through comparison, research and reading relative literatures I build out of the index structure system of partner selection, using the most advanced scientific interval value method, DEA method I determine the weight of each index, finally demonstrate scientific nature, the validity of this achievement through the example, provide the scientific basis and principles for us to select partner, find that the index weight is more accurate and fair, make up for the deficiency of the objectivity.
\end{abstract}

\section{Introduction}

The research is rich in the field of the whole enterprise, but the research is scarce in the field of the construction industry around the worldwide. [1] The domestic research and the practice is late, more influential viewpoints as follows: zhanglingxing's A Research on the Supplier's Selecting Based on the Pattern of Partnering in SC of Construction Industry; guoshuwen's A Research on Evaluation and Selection Method of Partner in SC of Construction Industry; zhouliang, quhongjian, zhengjianguo's A Selection of Strategic Partner in SC of Construction Industry; wangyaowu, zhengbaocai's A Research on Selective Criterion of Partner in SC of Construction Industry all have put forward their accomplished selective index system. Commonly manifested the following indicators: quality ensuring system, product qualification ratio, repair return ratio, order cost, transportation cost, stock cost, product price, use ratio of cost expense, punctual delivery ratio, order fill ratio, order lead time, the ability to take urgent orders, market share, sales ratio of growth etc. [2]

Throughout all the index system find the following problems and defects: (1) Indexs have been still lack of scientific nature: continued to use the traditional appraisal way, been Lack of a systematic and omni-directional index system, So accurately selecting partners on the whole is difficult.[3] (2) Have not determined the index weight or the determinate method was unscientific:

In terms of determination of the index weight, the existing methods (such as AHP, Delphi method, grey correlation method, DEA method, etc) in practical application all many or less have certain defects. Shortage of two aspects makes it necessary to discuss.

\section{The Construction of Index Structure System}

Selection Criteria of Partner's Product (or Service). The criteria is a evaluation of relative competitive advantage for the product or service provided by the partner, we should first consider whether the partner can provide certain competitive advantage product or the service in choosing a partner. Product competitiveness is mainly embodied in the product price, quality and flexible:

Price Aspect. In practical application, the product price can directly be compared, variable cost is often roughly estimated according to the product characteristics and practical experience. [4] For example: variable cost is a certain percentage of the price. If we assume that a partner's product " $A$ " price is $\mathrm{P}_{\mathrm{A}}$, variable cost paid by building enterprise is $\mathrm{S} \%$ of the price, the average price of the product is $\overline{\mathrm{P}_{\mathrm{A}}}$ in the same industry, average variable cost is $\overline{\mathrm{S}} \%$ of the average price (in fact, we 
can select a partner's price as standard price, because index itself calculated is the price comparison superiority),so a partner's price advantage is:

$$
\mathrm{P}=\frac{\mathrm{P}_{\mathrm{A}}(1+s \%)-\overline{\mathrm{P}_{\mathrm{A}}}(1+\overline{\mathrm{S}} \%)}{\overline{\mathrm{P}_{\mathrm{A}}}(1+\overline{\mathrm{S}} \%)} \times 100 \%
$$

Quality Aspect. The most direct quality index includes product qualification rate and percentage of repairing and exchanging purchase.

(1) Product Qualification Rate: It refers to the percentage of qualified product quantity to the total purchase quantity in a certain period of time. [5] Assume that a construction enterprise total procure $m$ products to the partner in a period of time, among them purchase product $i$ altogether $n$ times, the jth time $(1 \leqslant \mathrm{j} \leqslant \mathrm{n})$ purchase quantity is $\mathrm{PT}_{\mathrm{ji}}$, Among them qualified product quantity is $\mathrm{PQ}_{\mathrm{ji}}$, then in this time the product qualification rate provided by the partner is:

$$
\mathrm{PQR}=\frac{\sum_{\mathrm{j}=1}^{\mathrm{n}} \mathrm{PQ}_{\mathrm{ji}}}{\sum_{\mathrm{j}=1}^{\mathrm{n}} \mathrm{PT}_{\mathrm{ji}}} \times 100 \%
$$

Total product qualification rate is:

$$
\mathrm{PQR}=\frac{\sum_{\mathrm{i}=1}^{\mathrm{m}} \sum_{\mathrm{j}=1}^{\mathrm{n}} \mathrm{PQ}_{\mathrm{ji}}}{\sum_{\mathrm{i}=1}^{\mathrm{m}} \sum_{\mathrm{j}=1}^{\mathrm{n}} \mathrm{PT}_{\mathrm{ji}}} \times 100 \%
$$

If considering the value of the product (for the quantity of some small products maybe is very big, but the value is low), supposes the unit price of i product is $P_{i}$, then the above equation can be written to:

$$
\mathrm{PQR}=\frac{\sum_{\mathrm{i}=1}^{\mathrm{m}} \sum_{\mathrm{j}=1}^{\mathrm{n}} \mathrm{PQ}_{\mathrm{ji}} \times \mathrm{P}_{\mathrm{ji}}}{\sum_{\mathrm{i}=1}^{\mathrm{m}} \sum_{\mathrm{j}=1}^{\mathrm{n}} \mathrm{PT}_{\mathrm{ji}} \mathrm{P}_{\mathrm{ji}}} \times 100 \%
$$

If considering a product's important role to the construction enterprise, then may import the weight at the time of calculation, assume that weight is $r_{i}$, as a result:

$$
\mathrm{PQR}=\frac{\sum_{\mathrm{i}=1}^{\mathrm{m}=1} \frac{\sum_{\mathrm{j}=1}^{\mathrm{n}} \mathrm{PQ}_{\mathrm{ji}}}{\sum_{\mathrm{j}=1}^{\mathrm{n}} \mathrm{PT}_{\mathrm{ji}}}}{\sum_{\mathrm{i}=1}^{\mathrm{m}} \mathrm{r}_{\mathrm{i}}}
$$

(2) Percentage of Repairing and Exchanging Purchase: For the unqualified product (such as defective goods, exceed shelf-life, transportation loss, etc) in quality, usually should be returned to opposite party enterprise in the form of repair or return. Percentage of Repairing and Exchanging Purchase namely is the proportion of Cumulative quantity of Repairing and Exchanging Purchase and Total Product sale quantity for a period. [6] Assume that the construction enterprise purchase " $\mathrm{m}$ " kinds of products from a partner in a period of time, among them Purchase product" $\mathrm{i}$ "altogether $n$ times, the jth time $(1 \leq \mathrm{j} \leq \mathrm{n})$ purchase quantity is $\mathrm{TSM}_{\mathrm{ji}}$, among them qualified product quantity is $\mathrm{RE}_{\mathrm{ji}}$, then in this time" Percentage of Repairing and Exchanging Purchase" of the product " $i$ " provided by the partner is:

$$
\mathrm{P}_{\mathrm{RE}}=\frac{\sum_{\mathrm{j}=1}^{\mathrm{n}} \mathrm{RE}}{\sum_{\mathrm{j}=1}^{\mathrm{n}} \mathrm{TSM}_{\mathrm{ji}}} \times 100 \%
$$

Flexibility. It embodies an enterprise's reaction capacity to change of market's needs and customer's needs, the product flexibility mainly includes the flexibility of batch and the flexibility of type. [7] The enterprise's demand mean value for a product is $\bar{Q}$,output minimum value that partner " $A$ " can make a profit is $Q_{A M T N}$, maximum value is $Q_{A M A X}$, then flexibility of batch of partner " $A$ " can be expressed as:

$$
\mathrm{FOQ}_{\mathrm{A}}=\frac{\mathrm{Q}_{\mathrm{AMAX}}-\mathrm{Q}_{\mathrm{AMTN}}}{\overline{\mathrm{Q}}}
$$

Selection Index of Partner Own Ability. Financial Status. 
Table 1 Financial indexs and weights of partner's comprehensive selection

\begin{tabular}{|c|c|c|}
\hline criterion & index & Weight[\%] \\
\hline \multirow{2}{*}{ debt paying ability } & current ratio & 10 \\
\cline { 2 - 3 } & asset-liability ratio & 10 \\
\hline \multirow{2}{*}{ profit ability } & ROA & 5 \\
\cline { 2 - 3 } & ROC & 10 \\
\cline { 2 - 3 } & added value of wage & 5 \\
\hline \multirow{2}{*}{ economic efficiency } & Production and marketing balance rate & 10 \\
\cline { 2 - 3 } & sales growth rate & 10 \\
\hline \multirow{2}{*}{ development ability } & Social Contribution Rate & 10 \\
\cline { 2 - 3 } & Social rate of accumulation & 5 \\
\hline contribution ability & Project expenditure ratio & 10 \\
\cline { 2 - 3 } & & \\
\hline observing law and discipline & & \\
\cline { 2 - 3 }
\end{tabular}

The Innovation Ability and Development Potential.

Table 2 Indexs of the innovation ability and development potential

\begin{tabular}{|c|c|c|}
\hline aspect & criterion & index \\
\hline \multirow[t]{10}{*}{$\begin{array}{l}\text { Techn } \\
\text { ology }\end{array}$} & \multirow[t]{3}{*}{$\begin{array}{l}\text { level of human } \\
\text { resources }\end{array}$} & $\begin{array}{l}\text { Proportion of intermediate and senior technological title personnel to total number } \\
\text { of people }\end{array}$ \\
\hline & & ratio of scientific and technological personnel to enterprise staff \\
\hline & & ratio of $\mathrm{R} \& \mathrm{D}$ personnel to scientific and technological personnel \\
\hline & \multirow{5}{*}{$\begin{array}{l}\text { enterprise technical } \\
\text { level }\end{array}$} & ratio of available technological value to enterprise net output \\
\hline & & ratio of own technological value to enterprise net output \\
\hline & & ratio of own technological value to available technological value \\
\hline & & ratio of annual value of innovation to annual $\mathrm{R} \& \mathrm{D}$ expense \\
\hline & & enterprise $\square$ s technical capabilities of joint exploitation \\
\hline & \multirow{2}{*}{$\begin{array}{l}\text { technical level of } \\
\text { production method }\end{array}$} & advanced level and the second innovation of productive methods in enterprise \\
\hline & & advanced level and the second innovation of enterprise $\square \mathrm{s}$ equipment \\
\hline \multirow{6}{*}{$\begin{array}{l}\text { produ } \\
\text { ct }\end{array}$} & \multirow{3}{*}{$\begin{array}{ll}\text { current market } \\
\text { conditions }\end{array}$} & new product $\square \mathrm{s}$ market volume \\
\hline & & growth rate of new product $\square \mathrm{s}$ market volume \\
\hline & & new product market competition strength \\
\hline & \multirow{3}{*}{$\begin{array}{l}\text { new product market } \\
\text { situation }\end{array}$} & new product market share \\
\hline & & growth rate of new product sale income \\
\hline & & ratio of new product income to total sale income \\
\hline \multirow{7}{*}{$\begin{array}{l}\text { Organ } \\
\text { izatio } \\
\mathrm{n} \text { and } \\
\text { mana } \\
\text { geme } \\
\mathrm{nt}\end{array}$} & \multirow{4}{*}{$\begin{array}{l}\text { quantitative index of } \\
\text { Management }\end{array}$} & rationality of management level \\
\hline & & quantity ratio of technical personnel and administrative personnel \\
\hline & & ratio of administrative personnel to enterprise personnel \\
\hline & & shareholding ratio of management personnel \\
\hline & \multirow{3}{*}{$\begin{array}{l}\text { qualitative index of } \\
\text { Management }\end{array}$} & entrepreneur $\square \mathrm{s}$ appetite to risk \\
\hline & & entrepreneur $\square \mathrm{s}$ familiar degree to innovation produce market \\
\hline & & enterprise $\square \mathrm{s}$ incentive degree to Stockholder $\square \mathrm{s}$ rights of employee \\
\hline \multirow{6}{*}{$\begin{array}{l}\text { Input- } \\
\text { output } \\
\text { efficie } \\
\text { ncy }\end{array}$} & \multirow{3}{*}{$\begin{array}{l}\text { investment } \\
\text { technological } \\
\text { innovation }\end{array}$} & $\mathrm{R} \& \mathrm{D} \square \mathrm{s}$ expenditure increasing rate \\
\hline & & $\mathrm{R} \& \mathrm{D} \square \mathrm{s} \quad$ ratio of average expense to enterprise sale income \\
\hline & & $\mathrm{R} \& \mathrm{D} \square \mathrm{s} \quad$ ratio of evaluation expense to enterprise net profit \\
\hline & \multirow{3}{*}{$\begin{array}{l}\text { investment } \\
\text { efficiency }\end{array}$} & ratio of new product profit to $\mathrm{R} \& \mathrm{D} \square \mathrm{s} \quad$ average expense \\
\hline & & growth rate of new product profit and tax amount \\
\hline & & ratio of new product Sale volume to enterprise product sale profit \\
\hline
\end{tabular}


Selection Index of Partner's Cooperation Ability. The selection index includes punctual delivery ratio, urgent response ratio, owner complaint's solution time, owner complaint's satisfaction processing ratio. [8]

Selection Index of Partner's Sustainable Development Ability. The selection index includes enterprise culture; political, economic and technical culture; social relations and society repay.

\section{Using Advanced Scientific Method to Determine the Index's Weight}

Using DEA Method to Determine the Index's Objective Weights. Namely there are " $n$ " partners participating in the competition, Divide its appraisal index into two kinds for partner " $\mathrm{j}$ " $(\mathrm{j}=1,2, \ldots$, $\mathrm{n}): \mathrm{x}_{\mathrm{ij}}(\mathrm{i}=1,2, \ldots, \mathrm{m})$ the smaller the better (Corresponding to the input index) and $\mathrm{y}_{\mathrm{rj}}(\mathrm{r}=1,2, \cdots, S)$ the bigger the better. two partners " $\mathrm{A}$ " and " $\mathrm{B}$ " of any index for " $\mathrm{n}$ " partners, According to the following formula to calculate relative efficiency index, respectively. [9]

$$
\begin{aligned}
& \mathrm{E}_{\mathrm{AB}}={ }_{\mathrm{u}_{\mathrm{r}} \mathrm{v}_{\mathrm{i}}}^{\max } \sum_{\mathrm{r}=1}^{\mathrm{s}} \mathrm{u}_{\mathrm{r}} \mathrm{y}_{\mathrm{rA}} \quad \sum_{\mathrm{i}=1}^{\mathrm{m}} \mathrm{v}_{\mathrm{i}} \mathrm{x}_{\mathrm{iA}}=1, \sum_{\mathrm{r}=1}^{\mathrm{s}} \mathrm{u}_{\mathrm{r}} \mathrm{y}_{\mathrm{rA}}=1 \quad \sum_{\mathrm{r}=1}^{\mathrm{s}} \mathrm{u}_{\mathrm{r}} \mathrm{y}_{\mathrm{rB}}-\sum_{\mathrm{i}=1}^{\mathrm{m}} \mathrm{v}_{\mathrm{i}} \mathrm{x}_{\mathrm{iB}} \leqslant 0 \quad \text { then } \\
& \mathrm{E}_{\mathrm{BA}}={ }_{\mathrm{u}_{\mathrm{r}} \mathrm{v}_{\mathrm{i}}} \sum_{\mathrm{r}=1}^{\mathrm{s}} \mathrm{u}_{\mathrm{r}} \mathrm{y}_{\mathrm{rB}} \\
& \sum_{\mathrm{i}=1}^{\mathrm{m}} \mathrm{v}_{\mathrm{i}} \mathrm{x}_{\mathrm{iB}}=1, \quad \sum_{\mathrm{r}=1}^{\mathrm{s}} \mathrm{u}_{\mathrm{r}} \mathrm{y}_{\mathrm{rB}}=1, \quad \sum_{\mathrm{r}=1}^{\mathrm{s}} \mathrm{u}_{\mathrm{r}} \mathrm{y}_{\mathrm{rA}}-\sum_{\mathrm{i}=1}^{\mathrm{m}} \mathrm{v}_{\mathrm{i}} \mathrm{x}_{\mathrm{iA}} \leqslant 0
\end{aligned}
$$

And then calculate ratio " $\mathrm{a}_{A B}$ " of relative index efficiency for partners " $A$ " and " $B$ "

$$
\mathrm{a}_{\mathrm{AB}}=\frac{\mathrm{E}_{\mathrm{AB}}}{\mathrm{E}_{\mathrm{BA}}}
$$

Then, when $a_{A B}<1$, it means partner " $A$ " better than " $B$ " in the index; $a_{A B}=1$, it means both are about the same; if $a_{A B}>1$, it means partner " $B$ " better than " $A$ ". then according to the relative efficiency construct judgment matrix, the index weight is calculated for each partner.

Using Interval Value to Construct Judgment Matrix. May construct sector matrix of criterion level and the scheme level according to the correlation definition, after obtaining the sector judgment matrix, using interval characteristic root method to calculate each programm's weight to criterion level. [10]

\section{Conclusion}

$\mathrm{Z}$ construction enterprise select the most potential 3 feed partners for cooperation, according to the detailed information and exchanges data records, determine the index weight of selecting partner.

Using DEA Method Calculate Partner's Relative Efficiency, Construct Judgment Matrix and Obtain the Partner's Objective Weight. Using the formula

$$
\mathrm{K}=\sqrt{\sum_{\mathrm{j}=1}^{\mathrm{n}} \frac{1}{\sum_{\mathrm{i}=1}^{\mathrm{n}} \mathrm{a}_{\mathrm{ij}}^{+}}} \text {, relative efficiency respectively can be obtained } \mathrm{a}_{\mathrm{CB}}=\mathrm{E}_{\mathrm{CB}} /
$$

$\mathrm{E}_{\mathrm{BC}}=0.333, \mathrm{a}_{\mathrm{CA}}=0.47, \mathrm{a}_{\mathrm{BA}}=0.248$, comparison matrix between each partner is constructed as shown below:

$$
\begin{aligned}
& 1 \quad 1 / 0.248 \quad 1 / 0.47 \\
& \mathrm{~A}=0.248 \quad 1 \quad 1 / 0.333 \\
& \begin{array}{lll}
0.47 & 0.333 & 1
\end{array}
\end{aligned}
$$

Using FAHP, 1.1.5 ${ }^{6}$ and Interval Value to Construct Weight. Based on the hierarchy structure of index system, with comparison of the two to layer-by-layer determine index's value of relative importance. Through1. 1. $5^{6}$ and interval value to construct judgment matrix and check the consistency, obtain all levels of index weight, Mhierarchical single sort and total sort, results in Table 3: 
Table 3 All levels of index weight, hierarchical single sort and total sort

\begin{tabular}{|l|l|l|c|}
\hline & priceB1 & qualityB2 & flexibilityB3 \\
\hline priceB1 & 1 & $1 / 1.5^{2-3}$ & $1.5^{3-4}$ \\
\hline qualityB2 & \multicolumn{1}{|c|}{$1.5^{2-3}$} & 1 & $1.5^{4-5}$ \\
\hline flexibilityB3 & $1 / 1.5^{3-4}$ & $1 / 1.5^{4-5}$ & 1 \\
\hline
\end{tabular}

Annotation: weightw ${ }^{0}=(0.285,0.472,0.243), \mathrm{CR}=0.027<0.1$, meet the consistency check.

\begin{tabular}{|l|l|l|}
\hline & flexibility of batchC31 & flexibility of typeC32 \\
\hline flexibility of batcC31 & 1 & $1.5^{1}$ \\
\hline flexibility of typeC32 & $1 / 1.5^{1}$ & 1 \\
\hline
\end{tabular}

Annotation: weightw ${ }^{1}=(0.587,0.413), \mathrm{CR}=0.073<0.1$, meet the consistency check.

\begin{tabular}{|l|l|c|}
\hline & product qualified rateC21 & repair return ratioC22 \\
\hline product qualified rateC21 & 1 & $1.5^{1-2}$ \\
\hline repair return ratioC22 & $1 / 1.5^{1-2}$ & 1 \\
\hline
\end{tabular}

Annotation: weightw ${ }^{2}=(0.601,0.399), \mathrm{CR}=0.033<0.1$, consistency indexs are within the scope of permissible error, so all the relative important degree is acceptable, each index weight in Table 4:

Table 4 Product selection index weight

\begin{tabular}{|l|l|l|l|l|}
\hline B-C & B1 & B2 & B3 & P (weight) \\
\hline- & 0.285 & 0.472 & 0.243 & - \\
\hline C11 & 0.285 & - & - & 0.285 \\
\hline C21 & - & 0.601 & - & 0.2837 \\
\hline C22 & - & 0.399 & - & 0.1883 \\
\hline C31 & - & - & 0.587 & 0.1426 \\
\hline C32 & - & - & 0.413 & 0.1004 \\
\hline
\end{tabular}

Integration Weight. using the formula $\Psi_{i}=\lambda a_{i}+(1-\lambda) \beta_{i}$, order $\lambda=0.5$, three partners' synthesis weight can be determined respectively according to it $(0.4021,0.3487,0.2492)$.From the results we can see partner " $A$ " synthesis weight is highest, It manifests partner " $A$ " index weight of product selection is highest, it and construction enterprise's examine to partner " $A$ " are generally consistent at ordinary times. Reason is that $\mathrm{Z}$ construction enterprise on the basis of the practical work experience for many years to select partner, it is relatively justice to a certain extent, Through the construction of index system of selecting partner to make up for a lack of objectivity, The calculative index weight of partner's selection by using improved FAHP is more accurate. Through the case we can see that determined each index and its weight are very scientific and effective, really to provide the scientific basis and principles for us selecting partner.

\section{References}

[1] Dickson G.W.An Analysis of Vender Selection System and Decisions [J] Joumal of Purchasing, 2013, 2(1): 5-17

[2] Weber C A, Current J, R Benton W C. Vendor Selection Criteria and Methods [J], European Journal of Operational Research, 2012, 50-2-18

[3] Yahya S, Kingsman B.Modelling amulti-objective Mlocmion problem in a governments ponsored entrepreneurd evelopment programme [J], European Journal of Operational Research, 2013, 136: 430-448

[4] Wilson E L. The Relative Importance of Supplie Selection Criteria: A Review and Update [J], International Journal of Purchasing and Materials Management. 2014, 25: 35---41 
[5] Johnson M, Partner Selection in the Agile Environment [A]. Creating the Agile Organization: Models, Metrics and Pilot [C]. Annual Conference Proceedings, 2013

[6] Patton WE. Use of human judgment models in industrial buyers'vendorSelection decisions[J], Industrial Marketing Management 2013, 25: 135-149

[7] Stevens J. Integrating the supply chain[J], International Journal of Physical Distribution and Material Management, 2014, 1 989: 3-8

[8] Lee $\mathrm{H}$ L, Bllington $\mathrm{C}$. The evoluation of SC-management, models and practices at Hewlett-Packard [J], Interfaces, 2013, 25(5): 42-63

[9] William T W, Alber KL. Understanding SC management [J], APICS-TPA, 2012, 99 (11: 23-45

[10] Brunell.T.Managing a multi company SC [J]. SC Management Review, Spring 2013, 12-15 